Smiljana Milinkov

Filozofski fakultet Univerziteta u Novom Sadu

$316.774: 316.344 .233(497.11)$

smilinkova@gmail.com

\title{
SIROMAŠTVO ŽENA - MEDIJSKA ISKLJUČENOST
}

Prema podacima za 2010. godinu, na nivou Evropske unije zabeležen je veći procenat žena kojima preti siromaštvo ili društvena isključenost nego muškaraca. Razlika u siromaštvu žena i muškaraca često se naziva rodnim jazom u siromaštvu. U Strategiji za smanjenje siromaštva koju je Vlada Srbije usvojila 2003. žene su prepoznate kao socijalno ranjiva grupa, često, ukoliko je slučaj o Romkinjama, ženama sa invaliditetom, samohranim majkama ili ženama iz seoskih sredina, višestruko marginalizovana. Međutim, u medijima je siromaštvo žena i danas gotovo nevidljivo. Analiza novinarskih tekstova iz oktobra 2010. potvrđuje medijsku isključenost svih socijalno ranjivih grupa, samim tim i žena. Cilj ovog $\operatorname{rada}^{1}$ je da istraži koliko i na koji način je predstavljeno siromaštvo žena u elektronskim i štampanim medijima godinu dana kasnije, 2011. godine, kao i kakva je slika žena u komentarima građana ostavljenim na tekstovima koji govore o siromaštvu na popularnim medijskim portalima u Srbiji.

Ključne reči: žene, siromaštvo, mediji, rodni jaz, medijska isključenost

\section{RODNI JAZ U SIROMAŠTVU}

Mada prema zvaničnoj statistici ne postoji razlika u procentu žena i muškaraca ugroženih siromaštvom, posebne analize pokazuju da se u zemljama u tranziciji pogoršava ekonomski položaj žena. „Iako su i žene i muškarci siromašniji, nezaposleniji i diskriminisaniji u vremenima krize, to sve po već postojećim mehanizmima rodne neravnopravnosti pogađa više žene, na podmukliji i dugotrajniji način“ (Mršević 2011:222). Među socijalno-ekonomskim uzročnicima rodnog jaza

1 Rad „Siromaštvo žena-medijska isključenost“ pripremljen u okviru Regionalnog programa podrške istraživanjima u oblasti društvenih istraživanja na Zapadnom Balkanu (RRPP), koji vodi Univerzitet u Friburgu, uz finansijsku podršku Švajcarske agencije za razvoj i saradnju (SDC). Mišljenja izneta u ovom izveštaju su mišljenja autora i ne predstavljaju nužno mišljenja SDC niti Univerziteta u Friburgu. 
u siromaštvu često se navodi i retradicionalizacija i repatrijarhalizacija društva, kao i konflikt uloga porodica-posao gde teret još nose žene (Strategija 2009). Često prava mera nejednakosti u rizicima od siromaštva između žena i muškaraca ostaje sakrivena, jer se podrazumeva da su resursi jednako distribuirani unutar domaćinstva, međutim istraživanja pokazuju da postoje nejednakosti u raspoređivanju novca. $\mathrm{U}$ domaćinstvima sa nižim prihodima zapaženo je da se svakodnevno raspoređivanje novca najčešće prepušta ženama, te da one u nastojanju da rasporede oskudna sredstva često redukuju sopstvenu potrošnju, kako bi zaštitile životni standard porodice (inkluzijakurs.info)

Prema nekim procenama, žene predstavljaju 70 odsto siromašnih u svetu i često su manje plaćene za svoj rad od muškaraca. Statistike pokazuju i da su žene češće u riziku od gladi od muškaraca zbog „sistemske diskriminacije u obrazovanju, zdravstvu, zapošljavanju i kontroli imovine“ (unifem.org). Prema Zorici Mršević, nezaposlenost i siromaštvo sa svoje strane daju osnova za širenje porodičnog nasilja, seksualnog i svakog drugo maltretiranja radnica na radnom mestu, smanjivanje mogućnosti političke participacije i sve veće isključenosti žena iz javnog života (Mršević 2011:223).

Kako bi se poboljšao položaj žena u Srbiji, 2009. godine usvojena je Nacionalna strategija za poboljšanje položaja žena $i$ unapređivanje rodne ravnopravnosti ${ }^{2}$, u kojoj se navodi da je ekonomska ravnopravnost ključni faktor za postizanje kvalitativnih pomaka za ravnotežu u odnosima žena i muškaraca. „Ukoliko nemaju jednake uslove i mogućnosti za ekonomsku samostalnost sve druge mere za unapređivanje ravnopravnosti polova imaju manje izgleda za uspeh" (Strategija 2009). Prema Strategiji mediji su jedna od ključnih oblasti za unapređivanje rodne ravnopravnosti jer imaju odlučujući uticaj na formiranje javnog mnjenja pošto se preko njih reflektuje slika o rodnim ulogama koje imaju i žene i muškarci. U ovom strateškom dokumentu navodi se da je važno da se aktivnosti i potrebe žena prikazuju na ozbiljan i adekvatan način, a jedan od predviđenih ciljeva je „afirmacija rodno senzitivnog medijskog delovanja“ kako bi se pristupilo promenama svesti i tradicionalnih obrazaca po kojima je ženi mesto u kući ili se tretira kao muški objekat (Strategija 2009). I u članu 41 Zakona o ravnopravnosti polova iz 2009. godine navodi se da su „sredstva javnog informisanja dužna da kroz svoje programe

2 U daljem tekstu Strategija. 
razvijaju svest o ravnopravnosti zasnovanoj na polu, te i da ,preduzimaju mere radi izmene društvenih i kulturnih obrazaca, običaja i prakse, koji uslovljavaju stereotipe, predrasude i diskriminaciju utemeljenu na ideji o podređenosti, odnosno nadređenosti određenog pola“ (Pajvančić, Petrušić, Jašarević 2010: 99). Međutim istraživanja pokazuju da mediji ili ignorišu ili stereotipiziraju ženu. Prema Dubravki ValićNedeljković, istraživanja „stereotipa“ i „socijalizacije“ ukazuju na medijsku praksu isključivanja žena, pre svega iz ozbiljnih televizijskih sadržaja (Valić-Nedeljković 2011: 448).

Medijska isključenost predstavlja odsustvo informacija na programima televizijskih i radio stanica, dnevnim i nedeljnim novinama o delu pripadnika društva, odnosno prisustvo medijskih sadržaja koji za posledicu imaju opravdavanje društvene isključenosti i diskriminacije, kao i nepoštovanje prava na identitet (zavodsz.gov. rs) Kao uzrok medijske isključenosti navodi se nasleđe izveštavanja nastalog tokom poslednje decenije prošlog veka, neregulisana oblast i komercijalizacija medija jer mediji nemaju ekonomski interes da izveštavaju o marginalizovanim grupama. Prema istraživanju o medijskoj dimenziji društvene isključenosti, koje je 2005. godine sproveo Britanski Savet u Turskoj, kao medijski isključene grupe navode se žene, deca, osobe sa invaliditetom, etno-religijske i seksualne manjine. Medijsku isključenost žene karakteriše, s jedne strane, naglašavanje njene tradicionalne uloge u porodici, a s druge njena seksualnost. Takođe, veoma mali broj tekstova je o ženama u javnoj i biznis sferi, a i kada se o ovim oblastima piše, piše se o ženama iz drugih država (zavodsz.gov.rs).

\section{METOD I CILJ ISTRAŽIVANJA}

Istraživanje „Siromaštvo žena-medijska marginalizacija“deo je istraživačkog projekta „Medijski diskurs o siromaštvu i socijalnoj isključenosti“"3, koji se bavi kritičkom analizom načina na koje lokalni, regionalni i nacionalni mediji izveštavaju

3 Medijski diskurs o siromaštvu i socijalnoj isključenosti je istraživački projekat koji je, pomoću Regionalnog programa promocije istraživanja na Zapadnom Balkanu, Odsek za medijske studije Filozofskog fakulteta u Novom Sadu sproveo 2010. i 2011. godine. Istraživački korpus u 2011. godini odnosio se na televizije: Televiziju Srbije, Televiziju Vojvodine, TV B92, TV 5, radio stanice: Radio Beograd, Radio Novi Sad, Radio Zrenjanin i Radio Sto plus iz novog Pazara i štampane medije Politika, Dnevnik, Večernje novosti i Narodne novine iz Niša, kao i dva medijska portala B92.net i Blic.rs. Mediji su praćeni od 14. do 28. oktobra 2011. godine. 
o siromaštvu i socijalnoj isključenosti u Srbiji. Prilikom analize medijskih tekstova koji govore o siromaštvu korišten je kvantitativno-kvalitativan metod analize diskursa. Kao interdisciplinarna nauka koja kritički preispituje društvo i kulturu u kojoj su realni sagovornici koji razmenjuju poruke, analiza diskursa pokazuje se kao najpogodnija za ovakav tip istraživanja (Pralica 2011: 80).

Jedinica analize bio je novinski tekst ili informativni televizijski ili radijski prilog. Holandski teoretičar Van Dijk navodi da autore koji se bave kritičkim studijama diskursa, pre svega, zanima kako su predstavljene marginalizovane grupe (žene, manjine, izbeglice, raseljena lica, rasno markirane osobe) i to u informativnim medijskim sadržajima koji imaju najviše uticaja na auditorijum, dakle vestima, izveštajima, intervjuima (Milinkov 2011: 148).

Istraživanje je zasnovano i na kvalitativnoj analizi sadržaja kako bi se dodatno sagledao kontekst vremena i prostora, te rekonstruisao sistem vrednosti koji prati izveštavanje o siromaštvu žena.

Mada je Strategija za smanjenje siromaštva Vlade Srbije još 2003. žene prepoznala kao socijalno ranjivu grupu, često, u slučaju Romkinja, žena sa invaliditetom, samohranih majki ili žena iz seoskih sredina, višestruko marginalizovanu, one su u medijima i dalje gotovo nevidljive. Analiza tekstova u novinama i televizijskih i radijskih priloga iz oktobra 2010. potvrđuje medijsku isključenost svih socijalno ranjivih grupa, te i žena. Cilj ovog rada je da istraži koliko i na koji način je predstavljeno siromaštvo žena u elektronskim i štampanim medijima godinu dana kasnije, 2011. godine, kao i kakva je slika žena u komentarima samih građana ostavljenih na popularnim medijskim portalima u Srbiji

\section{ANALIZA I REZULTATI}

Ukoliko se posmatraju zbirni rezultati za štampu, radio i televiziju analiziranih u drugoj polovini oktobra 2011. godine, od 188 medijskih tekstova žene se kao društveno isključena grupa pojavljuju u svega 12, što bi bilo šest procenata. Za razliku od televizije gde je siromaštvu žena posvećen samo jedan prilog, radio i štampa su podjednaki, pet i šest medijskih tekstova. U svega četiri teksta (1\%) žene su u poziciji subjekta, što znači da im je data prilika da govore, dok se nešto češće, u 13 tekstova (6\%) pojavljuju kao objekat. 


\section{Televizija}

Bez obzira što su analizirane informativne emisije republičkog i pokrajinskog javnog servisa koji su prema članu 78. republičkog Zakona o radiodifuziji dužni da proizvode i emituju programe namenjene svim segmentima društva, bez diskriminacije, siromaštvo žena se pominje samo u jednom televizijskom prilogu. Radi se o izveštaju emitovanom u Dnevniku 2 Radio-televizije Srbije sa konferencije koja je održana 17. oktobra 2011. godine na kojoj se govorilo o problemu trgovine ljudima. Radi se o pseudo događaju, prilog traje dva minuta a siromaštvo je samo jedna od više tema, te se može iščitati više dimenzija socijalne isključenosti. Siromaštvo žena se može navesti kao uzročnik problema trgovine ljudima.

Analiza priloga koji govore o siromaštvu emitovanih $u$ informativnim emisijama republičkog i pokrajinskoj javnog servisa, kao i komercijalnih televizija iz 2011. godine potvrdila je prethodna istraživanja koja su konstatovala da je televizijska slika siromaštva stereotipna i banalizovana. „Predstavljanje aktera je selektivno, ograničeno i daleko od prikazivanja celokupnog konteksta, odnosno svedeno na male delove slika koji nemaju tu snagu da dočaraju na pravi način ozbiljnu problematiku siromaštva“(Drašković 2011: 61). Kada je reč o siromaštvu žena može se konstatovati da je ono gotovo nevidljivo u centralnim informativnim emisijama televizija u Srbiji.

\section{2. Štampa}

U istraživanju iz 2010. godine, kada je reč o identifikaciji žena kao društveno isključene grupe, u štampanim medijima se od ukupno 95 nalaze svega tri teksta. (Milinkov 2011:152). Istraživanje štampanih medija iz oktobra 2011. godine (Dnevnik, Politika, niške Narodne novine i Večernje novosti) pokazalo je nešto veći broj tekstova, sedam, što predstavlja pet odsto ukupnih analiziranih tekstova. Tri teksta govore o problemu trudnica, bilo da je reč o kršenju prava preduzetnica ili pomoći trudnicama u pojedinim opštinama, kao što je projekat „Trudnoćom do radnog mesta,, koji se sprovodi u Nišu.

Izveštaj „Meštanke osnovale udruženje za podršku“ objavljen 18. oktobra 2011. godine u Narodnim novinama, govori o inicijativi za osnivanje udruženja žena iz sela Temska (opština Pirot) za posticaj ženama sa sela da se bave preduzetništvom, 
odnosno kako se navodi u tekstu „pokrenu biznis i počnu da zarađuju“. Radi se o prenetom agencijskom tekstu, a među subjektima se nalaze i žene iz pomenutog sela. Siromaštvo žena je u drugom fokusu, ono se ne navodi direktno u samom tekstu, čak ni kada se pominju rezultati istraživanja o položaju žena u pirotskom okrugu, već se samo uopšteno kaže da su „rezultati bili poražavajući ponižavajući za žene koje žive na selu“. Ovaj izveštaj pokazuje da se siromaštvu žena iz ruralnih sredina nije pristupilo istraživački već da je tema „nametnuta“ činjenicom da je održan okrugli sto na kojem je pokrenuta navedena inicijativa, te da je novinar/novinarka iskoristila priliku da snimi prisutne sagovornike/sagovornice. Tekst je ilustrovan neodgovarajućom fotografijom na kojoj se vide građani kako šetaju ulicom u Pirotu, te ne postoji direktna veza fotografije i teme teksta.

U niškim Narodnim novinama je 20. oktobra 2011. objavljen tekst naslovljen „Do posla putuje na konju“, koji govori o pravnici Nadi Gajić iz opštine Kuršumlija koja do posla „putuje“ na konju. Iako se radi o retkom primeru da mediji izveštavaju o svakodnevnom životu žene, sam pristup temi ukazuje da se ne može govoriti o rodnoj perspektivi već je priča odabrana zbog „egzotičnog“ načina na koji ova žena dolazi do radnog mesta. Takođe je primetna nedoslednost u upotrebi rodno senzitivnog jezika jer se prvo govori o pravnici a potom o sekretaru opštih pravnih poslova u opštini Kuršumlija, a u oba slučaja reč je o Nadi Gajić.

Večernje novosti su 26. oktobra objavile tekst "Silovao me je trudnu“ o ispovesti žene iz Sigurne kuće. Radi se o senzacionalističkom tekstu gde se u potpunosti navode podaci zlostavljane žene „Slađana P. (25) iz jednog sela nadomak Šapca“, sa detaljnim opisima samog čina nasilja, dok je problemu ekonomske zavisnosti žena od muževa koji ih zlostavljaju, kao i mogućem rešenju problema porodičnog nasilja posvećen mali deo teksta. Ovaj tekst se uklapa u stereotipnu sliku žene u medijima, jer se ona pojavljuje u svega nekoliko uloga- majka, domaćica, seksualni objekat, seksualna radnica ili žrtva nasilja.

Prema Jeleni Višnjić i Mirjani Mirosavljević, oblikovanje ženske rodne uloge u medijskim obrascima nikad nije bilo problematično jer se prezentacija žene svodi na njene porodične i seksualne funkcije, čime ona ispunjava svoju anatomsku misiju. (Višnjić, Mirosavljević 2008: 251).

Inače, prema podacima SOS telefona za žene i decu žrtve nasilja, siromaštvo je pre svega dimenzija života žena, jer preko 80 \% zlostavljanih žena koje se javljaju 
nemaju dovoljno novca da prežive. „Siromaštvo onemogućava ženama da izađu iz nasilja u porodici. Nasilje generiše siromaštvo, a nasilje i siromaštvo vode žene u izolaciju i ćutanje“ (zeneucrnom.org)

Iako je još 2009. Nacionalnom strategijom za poboljšanje položaja žena $i$ unapređivanje rodne ravnopravnosti predviđeno da se utiče na medije da „pitanjima porodičnog nasilja, zlostavljanja žena, trgovine ljudima i seks trafikinga, čije su žrtve najčešće žene, prilaze sa dužnim poštovanjem, bez senzacionalizma“, kao i da se mediji ohrabre da promovišu vrednosti i principe tolerancije, nediskriminacije i međusobnog uvažavanja među ženama i muškarcima. (Strategija 2009), analize novinskih tekstova i dalje pokazuju senzacionalizam u izveštavanju o nasilju u porodici.

\section{Radio}

U periodu istraživanja, druga polovina oktobra 2011. godine, na analiziranim radio stanicama (Radio Beograd, Radio Novi Sad, Radio Zrenjanin i Radio Sto plus iz Novog Pazara), žene se kao društveno isključena grupa pominju u pet priloga, što čini $11 \%$ ukupnih priloga koji su govorili o siromaštvu. U ostalim prilozima žene se pominju ali kao sagovornice u anketi ili uopšteno kao deo siromašnih, penzionera ili radnika. U navedenih nekoliko priloga koji se tematski bave ženama, siromaštvo se uglavnom nalazi u drugom fokusu i ono se ne pominje kao uzročnik problema.

$\mathrm{Na}$ Radio Zrenjaninu emitovan je izveštaj o poseti načelnice okruga ženi koja živi na selu povodom obeležavanja Dana žena sa sela. Zanimljivo je da je ovde prilika da govori data načelnici dok je žena sa sela, Ljubica Oljača, samo objekat o kome se govori. Novinar ili novinarka, nije navedeno autorstvo, nije prepoznao/ la problem siromaštva žena iz ruralnih sredina koje su u strateškim dokumentima prepoznate kao posebno osetljiva socijalna grupa.

Tri priloga na različitim radio stanicama posvećena su ženama žrtvama trgovine ljudima i tu se siromaštvo navodi kao uzročnik problema, međutim najčešće se radi o pseudo događajima, odnosno o ovom problemu se uglavnom izveštava kada se organizuju konferencije za novinare, a vrlo retko se radi o inicijativi samog novinara/novinarke.

Jedina zabeležena reportaža je emitovana na Radio Beogradu i govori o 
teškom životu srpske devojčice u Prizrenu. U ovom radijskom prilogu i majka i ćerka Evica i Milica Đorđević dobile su priliku da govore o svom problemu.

4. Internet portali - B92.net i Blic.rs

U tekstovima koji su na popularnim medijskim portalima postavljeni povodom Dana borbe protiv siromaštva, žene su kao društveno ugrožena grupa nevidljive jer se govori uopšteno o stanovnicima ruralnih sredina ili samohranim roditeljima. Zanimljivo je da se u tekstu koji se bavi poskupljenima osnovnih životnih namirnica na portalu B92.net ne pominju žene, ali je postavljena fotografija koja ukazuje na patrijarhalni obrazac da je jedna od osnovnih uloga žena da brinu o domaćinstvu.

Kao što je u medijskim tekstovima, a to je potvrdilo i ovo istraživanje, slika žene, a pogotovo siromašne žene marginalizovana i stereotipizirana, analiza je pokazala da su žene nevidljive i u komentarima građana. U preko 2.000 komentara koje su posetioci navedenih sajtova ostavili na tekstove o siromaštvu, u svega 14 se pominju žene. Jedan od retkih komenatara koji ukazuju na siromaštvo žena postavljen je na tekst u kom se prenosi izjava ministra poljoprivrede Dušana Petrovića da neće biti poskupljenja.

B92-14-7:5

kao majka dvoje dece koja idu u osnovnu skolu ovakve vesti samo mogu da nas obraduju. Ne zelim vise da placam mleko po 147 din kao sto sam radila na pocetku god (zorica, 14. oktobar 2011 13:52)

Iz komentara ostavljenih na tekst „Opštine bez para za plate trudnica” (Blic), takođe se ponavlja stereotipna slika žene čija je, po patrijarhalnom shvatanju, osnovna uloga i dužnost da bude majka i to prvenstveno u cilju očuvanja nacije.

B92-22-5:7

I onda se posle neko pita zašto popis pokazuje da nas je sve manje i manje... Sramota!

(Maxa, 22. oktobar 2011 13:32). 
B92-22-5:6

E, pa gospodo moja draga nemojte se onda cuditi sto svake godine nestane jedna manja opstina, bruka i sramota kad za nase majke nemate plata.

(Vlade UE, 22. oktobar 2011 11:38)

B92-22-5:1

eto zasto umire Srbija

(jasmina, 22. oktobar 2011 03:56)

Iz potpisanih komentara retko se može zaključiti da se radi o ženi, u najvećoj meri su u potpisu muška imena ili nešto neodređeno poput „mačak u čizmama, gost, banana država, kad jaganci utihnu i zlopamtilo“.

\section{ZAKLJUČAK}

Prema Univerzalnoj deklaraciji o demokratiji UN iz 1997. jednakost između žena i muškaraca je pitanje ljudskih prava, preduslov i pokazatelj održivog razvoja. Ta jednakost ne znači da će žene i muškarci postati isti, nego da prava, odgovornosti i mogućnosti ne zavise od toga da li je neko rođen kao žena ili kao muškarac. Žene su teže i na određen način sveobuhvatnije pogođene globalnom ekonomskom krizom. Više su izložene nezaposlenosti i siromaštvu, pojačanom trošenju njihovih kapaciteta putem neplaćenog domaćeg rada. „U Srbiji, kao i u drugim zemljama u tranziciji došlo je do jačanja patrijarhata i ,tihog” prebacivanja velikog dela odgovornosti za funkcionisanje i preživljavanje porodične zajednice na ženu u uslovima ekonomije preživljavanja" (Markov, Stanković 2011: 332-333). Istraživanje Republičkog zavoda za socijalnu zaštitu, pokazalo je da je jedan od najizraženijih oblika rodne diskriminacije strukturalna diskriminacija, koja podrazumeva „duboku nepravdu koju neke grupe trpe kao posledicu često nesvesnih predrasuda, pretpostavki i reakcija dobronamernih ljudi u običnoj komunikaciji, medijskih i kulturnih stereotipa i strukturalnih karakteristika birokratske hijerarhije i tržišnih mehanizama“" (Praćenje društvene isključenosti u Srbiji 2008:110).

Kao što u državnim izveštajima izostaju temeljnije rodno osetljive analize siromaštva, tako i mediji ženu ne prepoznaju kao društveno ranjivu kategoriju, u 
velikoj meri višestruko diskriminisanu. Mada je prema statistikama žena procentualno (51\%) više nego muškaraca i mada se navode kao jedna od društveno isključenih grupa, u medijima su one gotovo nevidljive, jer se ne pominju posebno već se uglavnom pojavljuju uopšteno kao siromašni, gladni, radnici ili penzioneri.

Za razliku od rezultata analize koji pokazuju skoro nevidljivost društveno isključenih grupa u medijima, urednici i novinari ${ }^{4}$ pojedinih novosadskih dnevnih listova, televizijskih i radio stanica upravo Rome, žene, decu,osobe sa invaliditetom, beskućnike i stare izdvajaju kao najsiromašnije kategorije u Srbiji.

Mislim da su žene ugrožene, čak i one žene koje rade. Zato što je njihova odgovornost ogromna. Imaju odgovornost prema deci koju su rodile, žele toj deci da pruže sve, da bi deca bila uključena u zajednicu i u društvo...A pri tom su, to nije neka moja fantazija,manje plaćene, teže dolaze do posla i mislim da možda žene mojih godina, ja sam ovde najstarija, seniorka, da, žene mojih godina najčešće ostaju bez posla. I da je njima je jako teško da se uključe, bez obzira, čak i najstručnije, prosto su negde postale marginalna grupa. Mislim da eto to je neka ciljna grupa o kojoj bih ja volela da društvo malo više povede račun. ${ }^{5}$

Urednici i novinari ove marginalizovane grupe prepoznaju kao najsiromašnije u Srbiji, međutim u medijskim tekstovima one se uglavnom pojavljuju uopšteno kao siromašni ili gladni čime se gubi dimenzija višestruke diskriminacije. Indikativno je i da, bez obzira što i novinari sebe smatraju siromašnim građanima jer je novinarstvo danas slabo plaćena profesija, o siromaštvu se ne piše jer, kako pojedini navode, narod zna kako živi i ne želi o tome još i da čita, gleda i sluša u medijima, već su mu potrebne „lagodnije“ teme. (Milinkov 2011.156).

Iako se u društvenu isključenost ubraja i medijska, što pokazuje i istraživanje štampanih elektronskih medija iz 2011. godine, sem istraživanja i sugestija, malo toga se radi na rešavanju tog problema. Stoga je neophodna dodatna edukacija i novinara i urednika, što bi trebalo da bude obavezu države, odnosno Tima za smanjenje siromaštva, kao deo implementacije Strategije za smanjene siromaštva.

$4 \quad$ Fokus-grupni intervju organizovan je krajem marta 2011. godine a učestvovali su novinari i urednici u štampanim i elektronskim medijima u Novom Sadu. (Milinkov, Smiljana (2011). Medijska isključenost višestruko diskriminisanih siromašnih grupa u Srbiji. Medijski diskurs o siromaštvu i socijalnoj isključenosti. Novi Sad: Filozofski fakultet:145-157) . 


\section{LITERATURA}

Drašković, Brankica (2011). Televizijska slika siromaštva i socijalne inkluzije u Srbiji. Medijski diskurs o siromaštvu i socijalnoj isključenosti. Novi Sad: Filozofski fakultet: 45-63.

Milinkov, Smiljana (2011). Medijska isključenost višestruko diskriminisanih siromašnih grupa u Srbiji. Medijski diskurs o siromaštvu i socijalnoj isključenosti. Novi Sad: Filozofski fakultet:145-157.

Milojević Ivana, Markov Slobodanka (2011). Uvod u rodne teorije. Novi Sad: Mediterran Publishing.

Mršević, Zorica (2011). Ka demokratskom društvu-rodna ravnopravnost. Beograd: Institut društvenih nauka.

Pajvančić Marijana, Petrušić Nevena, Jašarević Senad (2010). Komentar zakona o ranopravnosti polova. Beograd: Centar modernih veština.

Praćenje društvene isključenosti u Srbiji, (2008). Beograd: Republički zavod za socijalnu zaštitu. 57-67, 109-114.

Pralica, Dejan (2011). Analiza medijskog diskursa siromaštva i socijalne isključenosti u radijskim informativnim emisijama javnih servisa, komercijalnih medija i medija lokalnih zajednica. Medijski diskurs o siromaštvu i socijalnoj isključenosti. Novi Sad: Filozofski fakultet: 77-91.

Valić-Nedeljković, Dubravka (2011). „Rod i mediji“ u Uvod u rodne teorije. Novi Sad: Mediterran publishing: 447-459.

Višnjić, Jelena, Mirosavljević Mirjana. (2008) Problem reprezentacije roda u medijima. Neko je rekao feminizam. Beograd: Heinrich Böll Stiftung (Regionalna kancelarija za Jugoistočnu Evropu).

Zakon o radiodifuziji (“Službeni glasnik RS”, br. 42/2002, 97/2004, 76/2005, 79/2005 - dr. zakon, 62/2006, 85/2006, 86/2006 - ispr. i 41/2009).

Internet stranice:

Inkluzijakurs.info. Posećeno 21.0.2011. URL: :http://www.inkluzijakurs. info/modul.php?headerbar $=3 \& \mathrm{~m}=4 \& \mathrm{p}=22 \& \mathrm{t}=\mathrm{k} \& \mathrm{kp}=42$

Nacionalna strategija za poboljšanje položaja žena i unapređivanje ravnopravnosti polova (2009-2015). Posećeno 23.05.2012. URL: http://www. gendernet.rs/files/dokumenta/Domaci/Nacionalna_strategija_cir.pdf 
Strategija za smanjenje siromaštva Republike Srbije. Posećeno 25.05. 2012. URL: http://www.prsp.gov.rs/download/2.\%20Strategija\%20za\%20smanjenje\%20 siromastva\%20u\%20Srbiji\%20-\%20Glavni\%20tekst.pdf

Zeneucrnom.org. Posećeno 10.06.2012. URL: http://www.zeneucrnom.org/ index.php?option $=$ com_content\&task=view\&id=84\&Itemid=21\&lang $=\mathrm{sr}$

Smiljana Milinkov

WOMEN'S POVERTY - MEDIA MARGINALIZATION

\section{Summary}

According to data for year 2010 on the EU level, there has been a greater percentage of women at risk of poverty and social exclusion than men. The difference in the poverty of women and men is often called the gender gap in poverty. Although the Poverty Reduction Strategy of the Serbian Government from 2003 recognized women as a socially vulnerable group, often, if it is a case of Roma women, women with disabilities, single mothers or women from rural areas, they are multiply marginalized and almost invisible in the media. The analysis of journalistic texts from October 2010. confirms the media exclusion of all socially vulnerable groups, and the women as well. The aim of this paper is to investigate which way women's poverty is presented in both electronic and print media a year later, in 2011 and what is the image of women in the comments of readers left on the articles about poverty published in popular media portals in Serbia. Keywords: women, poverty, media, gender gap, media exclusion 